\title{
Effects of Nigella sativa Seed Extract on Perphenzine-Induced Muscle Rigidity in Male Mice
}

\author{
Mahsa Hadipour Jahromy ${ }^{1 *}$, Mokhtar Jalili², Ahmad Jamshidi Mohajer ${ }^{3}$, \\ Fatemeh Kamali Poor ${ }^{3}$, Shirin Mansoori Dara ${ }^{3}$ \\ ${ }^{1}$ Medical Sciences Research Centre, Tehran Medical Sciences Branch, Islamic Azad University, Tehran, Iran \\ ${ }^{2}$ Tehran Medical Sciences Branch, Islamic Azad University, Tehran, Iran \\ ${ }^{3}$ Medical Student, Tehran Medical Sciences Branch, Islamic Azad University, Tehran, Iran \\ Email: Jahromymh@yahoo.com
}

Received 11 June 2014; revised 10 July 2014; accepted 14 July 2014

Copyright (C) 2014 by authors and Scientific Research Publishing Inc.

This work is licensed under the Creative Commons Attribution International License (CC BY). http://creativecommons.org/licenses/by/4.0/

(c) (i) Open Access

\begin{abstract}
Parkinson's disease (PD) is a degenerative disorder of the central nervous system. Early in the course of the disease, the most obvious symptoms are movement-related, including: shaking, rigidity, slowness of movement and difficulty with walking and gait. Rigidity is stiffness and resistance to limb movement caused by increased muscle tone, an excessive and continuous contraction of muscles. Effects of different herbal preparations have been evaluated on muscle rigidity so far and some of them are approved in clinic. In the present research, the effects of Nigella sativa hydroalcoholic seed extract on muscle stiffness in perphenazine-induced muscle rigidity were evaluated in adult male mice. In this experimental study, L-dopa $10 \mathrm{mg} / \mathrm{kg}$, Nigella sativa hydroalcoholic seed extract at 50,100 , and $200 \mathrm{mg} / \mathrm{kg}$ were administered orally to male Balb/c mice for 12 days. Control group only received water. Muscle rigidity scores were then measured and compared. The muscle rigidity score in group receiving extract at $50 \mathrm{mg} / \mathrm{kg}$ had no significant difference with control group but at $100 \mathrm{mg} / \mathrm{kg}$ it had been significantly improved starting at the 40th minute. The extract at $200 \mathrm{mg} / \mathrm{kg}$ had significant difference in all times measured in comparison with control group that also showed lower scores compared to L-dopa treated group. According to the obtained results in this study, it can be concluded that Nigella sativa hydroalcoholic extract has good effects on muscle rigidity in dose-dependent pattern.
\end{abstract}

\section{Keywords}

Nigella sativa, Parkinson, Muscle Rigidity

\footnotetext{
${ }^{*}$ Corresponding author.
}

How to cite this paper: Jahromy, M.H., Jalili, M., Mohajer, A.J., Poor, F.K. and Dara, S.M. (2014) Effects of Nigella sativa Seed Extract on Perphenzine-Induced Muscle Rigidity in Male Mice. World Journal of Neuroscience, 4, 313-318. 


\section{Introduction}

Nigella sativa is a dicotyledonous medicinal plant, belonging to the family of Ranunculaceae, which is native to southern Europe, North Africa, and Asia but widely cultivated in Pakistan and India. The plant reproduces capsulated fruits containing numerous white trigonal seeds, when being exposed to air, it turns black thus commonly known as Black Seed [1] [2]. Among the Muslim and Arabian communities, it is well known as Habbat Albarakah, Alhabahat Alsawda, and Alkamoun Alaswad. Various names in different languages have been referred, for instance, Shuniz, Khodhira, Black Cumin, or even as Black Caraway [3]. As is established historical and religion-based, it is advised for a wide range of health problems, and is one of the herbal medicines that are being actively investigated and thus has worldwide recognition [4].

Reviews have reported antioxidant and neuroprotective effects of Nigella sativa in addition to many other therapeutic effects, such as antitumor, immunopotentiation, anti-inflammatory, and antimicrobial [2] [5] [6]. According to some studies, it appears that this plant may have anti-depression and anti-Parkinson effects [7] [8].

Parkinson disease (PD) is a progressive neurodegenerative disease that affects between 100 and 200 per 100,000 people over 40, and over 1 million people in North America alone [9] [10]. PD is uncommon in people younger than 40, and the incidence of the disease increases rapidly over 60 years, with a mean age at diagnosis of 70 years [11]. The main features of PD are tremor, bradykinesia, and rigidity. A fourth feature, postural instability, is commonly mentioned, although it does not generally occur until much later in the course of the disease and is thus not included in any published diagnostic criteria for PD [12] [13]. The array of pharmacologic and surgical treatments available for the treatment of idiopathic PD is broader than any other degenerative disease of the central nervous system. Management of individual patients requires careful consideration of a number of factors including the patient's symptoms and signs, age, stage of disease, degree of functional disability, and level of physical activity and productivity [14].

Rigidity is stiffness and resistance to limb movement caused by increased muscle tone, an excessive and continuous contraction of muscles [12]. In Parkinsonism the rigidity can be uniform or ratchety (cogwheel rigidity) [12] [13]. The combination of tremor and increased tone is considered to be at the origin of cogwheel rigidity. Rigidity may be associated with joint pain; such pain being a frequent initial manifestation of the disease. In early stages of Parkinson's disease, rigidity is often asymmetrical and it tends to affect the neck and shoulder muscles prior to the muscles of the face and extremities. With the progression of the disease, rigidity typically affects the whole body and reduces the ability to move [11]-[14].

During the last decades, potential effects of folk medicinal plants on muscle rigidity have been elicited. In the present research, we report black seed extract effects in perphenazin-induced muscle rigidity compared to L-dopa effect in male mice.

\section{Methods}

Fifty male adult Balb/c mice aged 8 weeks old (weighing from 20 - 25 g) were acquired from the Pasteur institute of Tehran and allowed to acclimatize to 12 hours of light and 12 hours of darkness per day. Animals were randomly divided into five groups of ten mice in each. In this experimental study, L-dopa at $10 \mathrm{mg} / \mathrm{kg}$, Nigella sativa hydroalcoholic seed extract at 50,100, and $200 \mathrm{mg} / \mathrm{kg}$ doses were administered orally via feeding needle to male Balb/c mice for 12 days. Control group only received water.

Muscular rigidity (usually named catatonia) was determined using the method of Morpurgo (8). The development of muscle rigidity was observed and scored as follows: Stage 1, mice move freely when placed on the table, score allocated $=0$; Stage, mice move only when touched or pushed, score allocated $=0.5$; Stage 3 , mice placed on the table with one of the front paws alternately on a $1 \mathrm{~cm}$ high block. Fail to correct the posture in 10 seconds, score allocated $=0.5$ for each paw with a total score of 1 for this stage. Stage 4 , mice fail to correct the posture in 10 seconds when the front paws are placed alternately on a $3 \mathrm{~cm}$ high block, score allocated $=1$ for each paw with total score of 2 for this stage. Thus, for a single animal, the maximum possible score would be 3.5 reflecting total muscle rigidity. Low score would mean an apparently lower degree of muscle rigidity. Muscular rigidity was determined at 20, 40, 60, 90, 120, 180 and 240 min after injections.

Black seeds were purchased from a local herb market, cleaned, dried, mechanically powdered, extracted with $70 \%$ ethanol and dried, with rotary evaporator to render the extract alcohol free and kept in refrigerator at 4 degree centigrade until used. The seeds extract was provided at doses of 50, 100, $200 \mathrm{mg} / \mathrm{kg}$ and administered orally for 12 days. Half an hour after the last dose on day 12, perphenazin $10 \mathrm{mg} / \mathrm{kg}$ was injected intraperito- 
neally and after 20 minutes muscle rigidity test was performed.

The data were subjected to Analyses of Variances (ANOVA). The analyses were performed using the SPSS statistical software for Windows Version 13. P $<0.05$ was regarded as statistically significant.

\section{Results}

After analysis of the scores obtained from different groups at different times, the following results were derived: L-dopa at $10 \mathrm{mg} / \mathrm{kg}$ improved muscle rigidity significantly at most detected times (Figure 1). The muscle rigidity scores in group receiving extract at $50 \mathrm{mg} / \mathrm{kg}$ had no significant difference with control group (Figure 2). However, using extract at $100 \mathrm{mg} / \mathrm{kg}$, muscle stiffness had been significantly improved starting at 40th minutes and lasted till the end of experiment (Figure 3). The muscle rigidity scores when extract at $200 \mathrm{mg} / \mathrm{kg}$ administered, had significant difference in all times measured in comparison with control group (Figure 4).

\section{Discussion}

In the present study it was observed that hydroalcoholic seed extract of Nigella sativa improves muscle rigidity

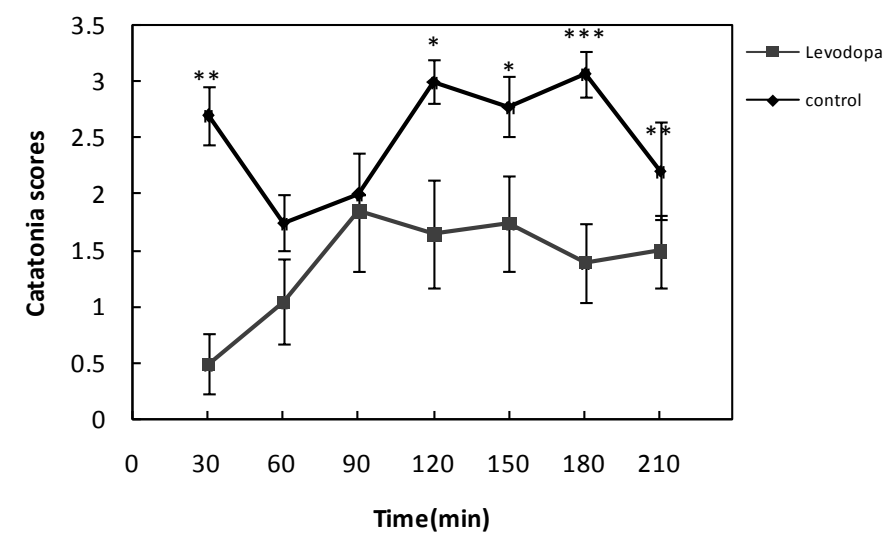

Figure 1. Comparison of perphenazine-induced muscular rigidity between L-dopa at $10 \mathrm{mg} / \mathrm{kg}$ treated and control group. * indicates significant difference $\left({ }^{* *} \mathrm{P}<0.01,{ }^{* * *} \mathrm{P}<0.001\right)$.

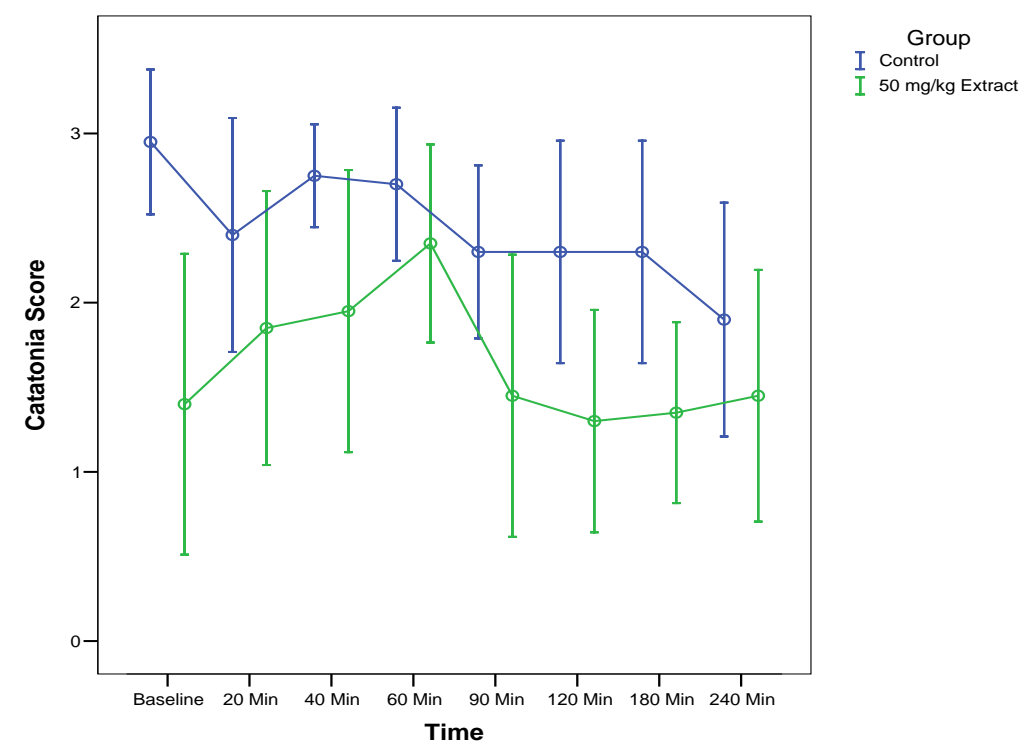

Figure 2. Comparison of perphenazine-induced muscular rigidity between Nigella sativa extract at $50 \mathrm{mg} / \mathrm{kg}$ treated and control group. * indicates significant difference $(\mathrm{P}<0.05)$. 


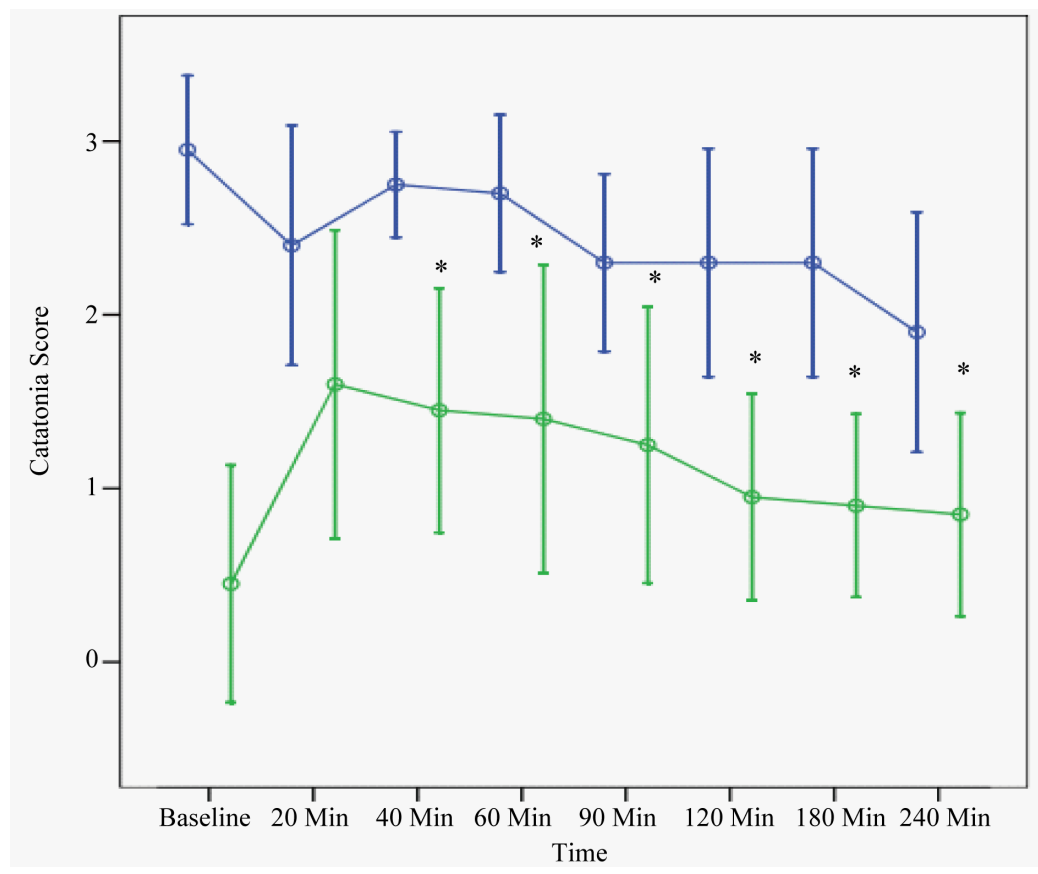
I Control
I $100 \mathrm{mg} / \mathrm{kg}$ Extract

Figure 3. Comparison of perphenazine-induced muscular rigidity between Nigella sativa extract 100 $\mathrm{mg} / \mathrm{kg}$ treated and control group. * indicates significant difference $\left({ }^{*} \mathrm{P}<0.05\right)$.

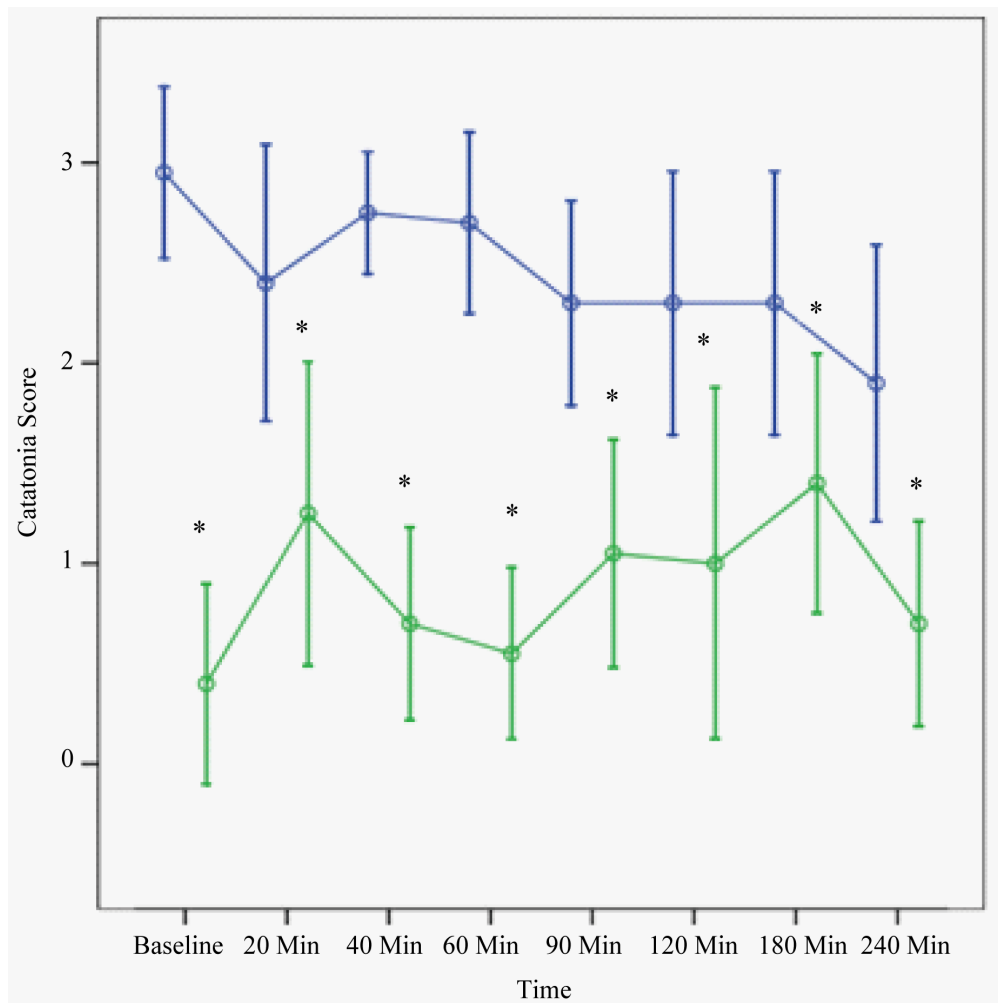

Group
I Control
I $200 \mathrm{mg} / \mathrm{kg}$ Extract

Figure 4. Comparison of perphenazine-induced muscular rigidity between Nigella sativa extract 200 $\mathrm{mg} / \mathrm{kg}$ treated and control group. * indicates significant difference $\left({ }^{*} \mathrm{P}<0.05\right)$.

dose-dependently, in mice.

Parkinson's disease is an age-related disorder characterized by progressive degeneration of dopaminergic 
neurons mostly in substantia nigra [9]. Perphenazine is among typical neuroleptic medicines; commonly use to induce muscle rigidity, reflecting PD in animal models. Due to unknown etiology of PD, it is difficult to develop therapeutic approaches to stop the progression of the disease. To date, L-dopa or dopaminergic agonists are the best known treatment however their permanent use has limitations because of their serious side effects. Thus, the need to develop new therapeutic or supplement agents requires [10] [11]. Epidemiological data suggest that antioxidants may have a beneficial effect on many neurodegenerative diseases including PD and muscle rigidity [12]. Interest in the relationship between antioxidants and muscle stiffness led to some trials that reported effectiveness of vitamin C and vitamin E in PD [15]. Many herbal medicines contain high level of antioxidants and therefore can be good candidates for catatonia research. Some studies reported that Nigella sativa can be effective in the treatment of neurological diseases such as depression [7] [16]. Also, in one study, the protective effect of thymoquinone, one of the main chemicals in black seed on dopamine-producing cells against MPP+ and rotenone has been confirmed [8]. The results of this study confirmed usefulness of antioxidants existing in black seed; however, this hypothesis needs to be tested clinically.

\section{Conclusion}

Overall, according to the present research and other related studies, it is believed that black seed can improve muscle rigidity very well compared to L-dopa. According to our study, these effects appear to be dose-dependent. It can be attributed to its antioxidant properties reported to be high in black seed. Further studies are recommended to confirm the findings obtained, especially on human subjects.

\section{References}

[1] Khan, M.A. (1999) Chemical Composition and Medicinal Properties of Nigella sativa Linn. InflammoPharmacology, 7, 15-35. http://dx.doi.org/10.1007/s10787-999-0023-y

[2] Salem, M.L. (2005) Immunomodulatory and Therapeutic Properties of the Nigella sativa L. Seed. International Immunopharmacology, 5, 1749-1770. http://dx.doi.org/10.1016/j.intimp.2005.06.008

[3] El-Tahir, K.E.D.H. and Bakeet, D.M. (2006) The Black Seed Nigella sativa Linnaeus—A Mine for Multi Cures: A Plea for Urgent Clinical Evaluation of Its Volatile Oil. Journal of Taibah University Medical Sciences, 1, 1-19. http://dx.doi.org/10.1016/S1658-3612(06)70003-8

[4] Goreja, W.G. (2003) Black Seed: Nature’s Miracle Remedy. Amazing Herbs Press, New York.

[5] Ashraf, S.S., Rao, M.V., Kaneez, F.S., et al. (2011) Nigella sativa Extract as a Potent Antioxidant for PetrochemicalInduced Oxidative Stress. Journal of Chromatographic Science, 49, 321-326. http://dx.doi.org/10.1093/chrsci/49.4.321

[6] Kanter, M. (2008) Nigella sativa and Derived Thymoquinone Prevents Hippocampal Neurodegeneration after Chronic Toluene Exposure in Rats. Neurochemical Research, 33, 579-588. http://dx.doi.org/10.1007/s11064-007-9481-z

[7] Hosseini, M., Zakeri, S., Khoshdast, S., et al. (2012) The Effects of Nigella sativa Hydro-Alcoholic Extract and Thymoquinone on Lipopolysaccharide-Induced Depression like Behavior in Rats. Journal of Pharmacy \& BioAllied Sciences, 4, 219-225. http://dx.doi.org/10.4103/0975-7406.99052

[8] Radad, K., Moldzio, R., Taha, M., et al. (2009) Thymoquinone Protects Dopaminergic Neurons against MPP+ and Rotenone. Phytotherapy Research, 23, 696-700.

[9] Marras, C. and Tanner, C.M. (2004) Epidemiology of Parkinson’s Disease. In: Watts, R.L. and Koller, W.C., Eds., Movement Disorders: Neurologic Principles and Practice, 2nd Edition, The McGraw-Hill Companies, New York, 177.

[10] Lang, A.E. and Lozano, A.M. (1998) Parkinson’s Disease. First of Two Parts. The New England Journal of Medicine, 339, 1044-1053. http://dx.doi.org/10.1056/NEJM199810083391506

[11] Van Den Eeden, S.K., Tanner, C.M., Bernstein, A.L., et al. (2003) Incidence of Parkinson’s Disease: Variation by Age, Gender, and Race/Ethnicity. American Journal of Epidemiology, 157, 1015-1022. http://dx.doi.org/10.1093/aje/kwg068

[12] Gelb, D.J., Oliver, E. and Gilman, S. (1999) Diagnostic Criteria for Parkinson Disease. Archives of Neurology, 56, 3339. http://dx.doi.org/10.1001/archneur.56.1.33

[13] Ward, C.D. and Gibb, W.R. (1990) Research Diagnostic Criteria for Parkinson's Disease. Archives of Neurology, 53, 245.

[14] Olanow, C.W., Watts, R.L. and Koller, W.C. (2001) An Algorithm (Decision Tree) for the Management of Parkinson's Disease (2001): Treatment Guidelines. Neurology, 56, S1. http://dx.doi.org/10.1212/WNL.56.suppl_5.S1 
M. H. Jahromy et al.

[15] Fahn, S. (1992) A Pilot Trial of High-Dose Alpha-Tocopherol and Ascorbate in Early Parkinson's Disease. Annals of Neurology, 32, S128-S132. http://dx.doi.org/10.1002/ana.410320722

[16] Butt, M.S. and Sultan, M.T. (2010) Nigellasativa: Reduces the Risk of Various Maladies. Critical Reviews in Food Science and Nutrition, 50, 654-665. http://dx.doi.org/10.1080/10408390902768797 
Scientific Research Publishing (SCIRP) is one of the largest Open Access journal publishers. It is currently publishing more than 200 open access, online, peer-reviewed journals covering a wide range of academic disciplines. SCIRP serves the worldwide academic communities and contributes to the progress and application of science with its publication.

Other selected journals from SCIRP are listed as below. Submit your manuscript to us via either submit@scirp.org or Online Submission Portal.
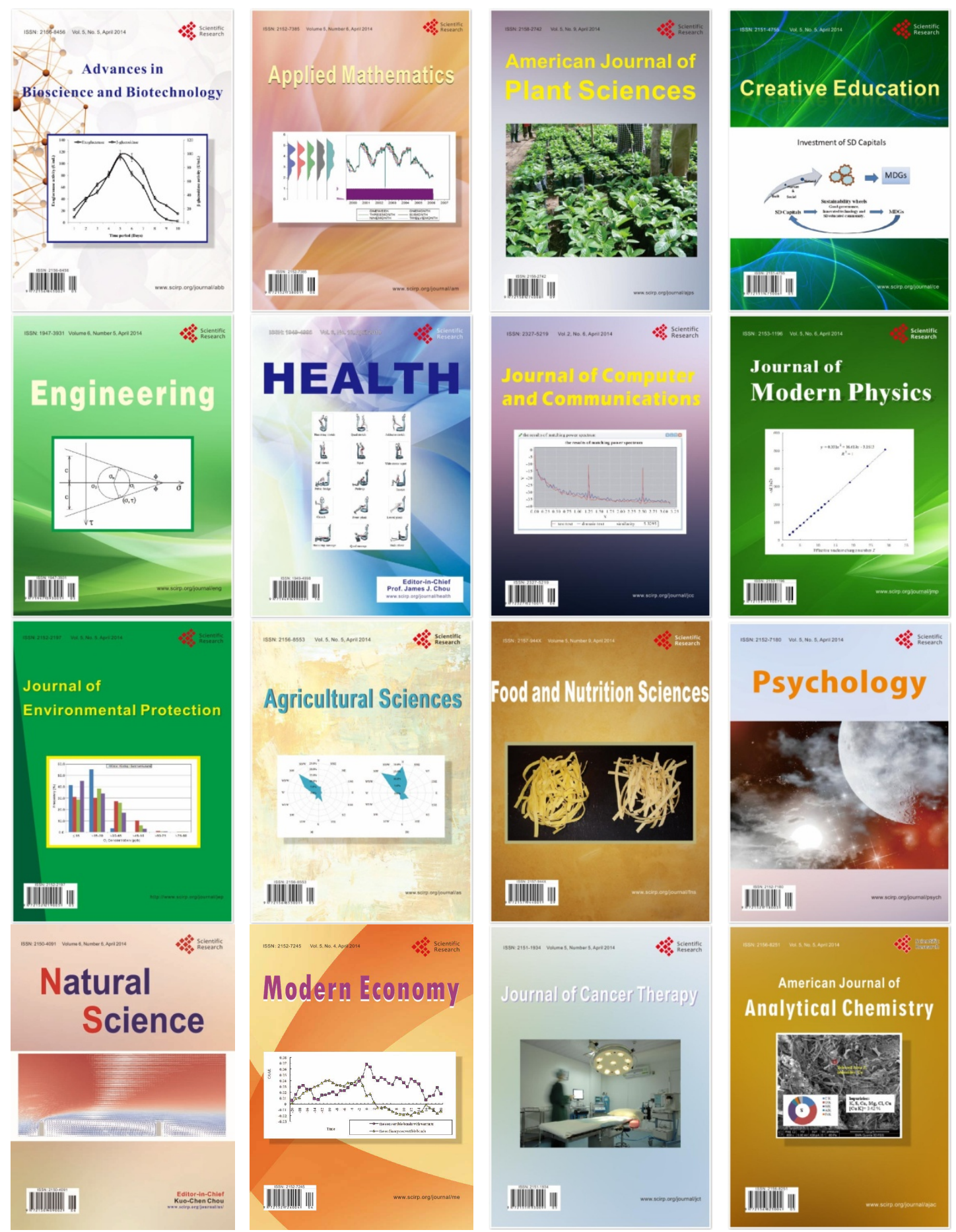